\title{
HUBUNGAN ANTARA KEBIASAAN LITERASI TERHADAP KETERAMPILAN BERBICARA DI KELAS 3 MIN 1 PRINGSEWU
}

\author{
Mela Fadila Tussani, Ruly Nadian Sari \\ Pendidikan Guru Madrasah Ibtidaiyah STIT Pringsewu \\ Pringsewu Lampung \\ Alamat : Jalan Raya Wonokriyo Gadingrejo Pringsewu 35373, Telp. 0729-333091 \\ Email: melafadila1003@gmail.com, rulynadiansari@gmail.com
}

\begin{abstract}
The problem in this study is that there are still students who have not been fluent in reading, and the lack of interest of students in this regard so that middle-class students in the level of development of the child still do not master the material at school. This goal is to find out the relationship between the habits of literacy towards speaking skills in class 3 MIN 1 Pringsewu. This type of research is quantitative research. Data collection techniques using questionnaires ( Questionnaries ) observation, interviews. The population in this study amounted to 217 students. The sample in this study were 25 students with cluster techniques at MIN 1 Pringsewu sub-district Pringsewu district. Data were analyzed using regression tests. With the known value of tarithmetic $=3,263$ with a significant value of $0,580<$ 0,05 , then $\mathrm{H} 0$ is accepted which means there is a ( significant ) effect of trust ( $\mathrm{x}$ ) variable on the participant variable ( $\mathrm{Y}$ ).
\end{abstract}

Keyword : Related Literacy, Speaking Skills

\begin{abstract}
Abstrak
Masalah dalam penelitian ini adalah masih adanya siswa yang belum lancar dalam membaca, dan kurangnya minat siswa dalam hal tersebut sehingga siswa tingkat kelas menengah tingkat perkembangan anak tersebut masih belum menguasai materi di sekolah. Tujuan ini untuk mengetahui hubungan antara kebiasaan literasi terhadap keterampilan berbicara di kelas 3 MIN 1 Pringsewu. Jenis penelitian ini adalah penelitian kuantitatif, teknik pengumpulan data menggunakan angket ( kuesioner ) observasi, wawancara. Populasi dalam penelitian ini berjumlah 217 siswa. Sampel dalam penelitian ini adalah 25 siswa dengan teknik cluster di MIN 1 Pringsewu Kecamatan Pringsewu Kabupaten Pringsewu. Data dianalisis menggunakan uji regression. Dengan diketahui nilai $\mathrm{t}$ hitung $=3,263$ dengan nilai siginifikan $0,580<0,05$, maka H0 ditolak dan H1 diterima yang berarti ada pengaruhnya yang nyata ( signifikan ) variable trust $(\mathrm{x})$ terhadap variable partisipan $(\mathrm{Y})$.
\end{abstract}

Kata kunci : Keterkaitan Literasi, Keterampilan Berbicara 


\section{A. PENDAHULUAN}

Kemampuan literasi adalah salah satu kebutuhan yang sangat penting untuk dimiliki setiap orang. Literasi adalah proses membaca, menulis, berbicara, mendengarkan, melihat dan berpendapat (Kuder \& Hasit, 2002). Literasi secara umum didefinisikan sebagai kemampuan membaca dan menulis serta menggunakan bahasa lisan. Literasi berfungsi untuk menghubungkan antara individu dengan masyarakat, serta merupakan suatu alat yang penting bagi individu untuk tumbuh dan berpartisipasi aktif dalam masyarakat yang demokratis. Sejalan dengan perkembangan tersebut, guru yang berada di sekolah harus berpikir bahwa literasi merupakan suatu konsep yang terus berkembang dan akan berkonsekuensi pada penggunaan berbagai media digital di kelas, sekolah, dan masyarakat.

Memperlakukan literasi sebagai konsep yang berkembang juga memungkinkan guru untuk melihat keanekaragaman budaya dan Bahasa, sebagai sumber daya yang berharga bagi siswa untuk terlibat dengan media digital yang baru, bukan sebagai konsumen, namun sebagai produsen yang kritis dan kreatif. Dengan demikian, pembelajaran literasi ditunjukan untuk mengembangkan keterampilan siswa dalam literasi kritis, literasi visual, litersi media, literasi teknologi, literasi lintas kurikulum (IPS, matematika,sains, seni, dan mata pelajaran lainnya), serta literasi dalam Bahasa lain.

Berdasarkan sudut pandang tersebut, dalam upaya membangun makna dapat dilakukan terhadap berbagai bentuk media komunikasi. Melalui media yang dapat di dekatkan dengan literasi dapat dianggap menyimpan makna, sehingga pengetahuan akan semakin berkembang jika makna-makna tersebut berbagai simbol representative yang dapat digali dan ditemukan. Pembelajaran literasi sebaiknya dilakukan dengan cara yang komprehensif untuk meningkatkan kemampuan akademik siswa, mengembangkan kompetensi budaya siswa, dan mengembangkan kesadaran sosial para siswa maupun guru.

Pembelajaran literasi juga harus ditujukan agar siswa memiliki berbagai kompetensi kritis atas teks dan menempatkan siswa sebagai anggota dari kelomok sosial budaya yang beragam. Pembelajaran literasi selanjutnya harus di pandang sebagai praktik sosial dan tindakan kelompok. Dalam pandangan ini, belajar

literasi di awali dengan mempelajari hubungan antara bunyi dengan tulisan. Kosakata / morfem adalah dasar untuk membaca. Oleh sebab itu, sebagian besar pembelajaran literasi permulaan menekankan penguasaan kosakata dan menghubungkan kosakata yang diucapkan anak ke kosakata tertulis. Biasanya, siswa secara resmi diperkenalkan aturan linguistic atau kognitif tertentu. Dalam mempelajari Bahasa, siswa harus terlebih dahulu belajar tentang sistem Bahasa dan strategi. Setelah proses ini di lalui, baru kemudian siswa di pandang dapat menggunakan kemahiran literasi untuk belajar. Pembelajaran literasi di sekolah dilaksanakan untuk mencapai tujuan tertentu. Tujuan pembelajaran literasi secara internasional diperluas dan diperinci.

Berdasarkan dokumen pada tahun 1998 dari The National Literacy Strategy (Wray et al.,2004:23). Guna mampu memiliki kemampuan berpikir tingkat tinggi, diperlukan kebiasaan yang baik. Sedangkan perpustakaan merupakan suatu sumber belajar yang biasanya ada pada setiap sekolah, didalam perpustakaan terdapat banyak buku-buku dan sumber belajar yang lainnya. Manfaat perpustakaan menurut Bafadal (2009 : 5) Perpustakaan sekolah dapat menimbulkan kecintaan siswa terhadap membaca, perpustakaan sekolah dapat memperkarya pengalaman belajar siswa, perpustakaan sekolah dapat menanamkan kebiasaan belajar mandiri yang akhirnya siswa dapat belajar dengan mandiri, perpustakaan sekolah dapat melatih siswa untuk bertanggung jawab, perpustakaan sekolah dapat memperlancar siswa dalam menyelesaikan tugas-tugas sekolah, perpustakaan sekolah dapat membentuk siswa, guru-guru dan staf sekolah dalam mengikuti perkembangan ilmu pengetahuan dan teknologi.

Karena di dalam perpustakaan lah dapat membantu siswa membentuk karakter dari siswa itu sendiri dan juga membuat siswa menjadi rajin untuk membaca. Kebiasaan berpikir yang baik diperlukan untuk berpikir tingkat tinggi meliputi keterbukaan, ketekunan, keingintahuan, dan kemandirian. Costa dan Kallick (2009) mendefinisikan kebiasaan pikiran sebagai sikap yang individu pilih/ambil ketika dihadapkan pada masalah yang tidak segera dapat dijawab. 
Costa dan Kallick (2009) percaya bahwa siswa harus mengembangkan kebiasaan berpikir sebab kebiasaan berpikir merupakan karakteristik kinerja tertinggi, yang dibutuhkan untuk menguasai berbagai bidang ilmu pengetahuan, dan wawasan. Berkenaan dengan tujuan pembelajaran literasi, perlu juga kiranya dikemukakan pendapat Morocco et al. (2008) tentang kompetensi yang perlu dikuasai pada abad ke-21. Dalam pandangan mereka, tujuan pembelajaran pada abad ke-21 adalah untuk mengembangkan empat pilar kompetensi abad ke-21 yakni pemahaman konsep yang tinggi, kemampuan berpikir kritis, kemampuan berkomunikasi dan berkolaborasi antara kebiasaan literasi terhadap berbicara didalam sekolah.

Keterampilan berbicara atau retorika adalah seni tentang berbicara yang dimiliki seseorang. Seni berbicara ini dimiliki seseorang secara alami atau dengan menggunakan latihan khusus. Keterampilan berbicara ini merupakan sarana komunikasi dengan Bahasa lisan meliputi proses penyampaian pikiran, ide, gagasan dengan tujuan melaporkan, menghibur, atau meyakinkan orang lain. Pada kegiatan berbicara tentu ada hal yang mendasari didalamnya, ada beberapa prinsip pokok, antara pembentukan paling sedikit yaitu dua orang, memakai Bahasa yang dipahami bersama, menerima atau mengakui daerah referensi umum.

Dari hal inilah kemudian diharapkan minat membaca dan menulis dapat ditumbuhkan pada siswa sejak dini melalui kegiatan literasi tanpa harus menunggu siswa tersebut mempunyai keterampilan membaca dan keterampilan menulis. Berdasarkan wawancara yang telah dilakukan kepada guru dan staf perpustakaan di MIN 1 Pringsewu bahwa masih banyak siswa yang kurang minat untuk membaca baik membaca di perpustakaan maupun membaca di dalam kelas. Bahkan di kelas rendah masih ditemukan beberapa siswa yang belum lancar membaca. Di dalam sekolah tersebut mempunyai banyak sekali buku-buku di perpustakaan baik buku-buku pelajaran di sekolah maupun buku-buku cerita dan buku-buku pengetahuan.

Minat siswa dalam membaca sangatlah kurang, karena anak-anak lebih suka bermain di dalam kelas dari pada harus membaca maupun menulis. Namun berdasarkan hal tersebut, di temukan masalah yaitu tentang "kurangnya minat belajar siswa dalam membaca di perpustakaan sekolah karena siswa tersebut lebih memilih mengobrol, bermain, pergi ke kantin dari pada harus membaca buku pelajaran maupun buku cerita yang ada di perpustakaan sekolah". Mengenai permasalahan tersebut maka, penulis ingin menyelesaikan permasalahan diatas sehingga penulis mengambil judul penelitian "Hubungan antara kebiasaan literasi terhadap keterampilan berbicara di kelas 3 MIN 1 Pringsewu".

$$
\begin{aligned}
& \mathrm{SB}=4 \\
& \mathrm{~B}=3 \\
& \mathrm{CB}=2 \\
& \mathrm{~TB}=1
\end{aligned}
$$

Indikator Keterampilan Berbicara

\begin{tabular}{|l|l|l|l|l|l|}
\hline NO & $\begin{array}{l}\text { INDIKATOR } \\
\text { KETERAMPILAN } \\
\text { BERBICARA }\end{array}$ & SB & B & CB & TB \\
\hline 1. & LAFAL & & & $\sqrt{ }$ & \\
\hline 2. & INTONASI & & $\sqrt{ }$ & & \\
\hline 3. & HAFALAN & & & $\sqrt{ }$ & \\
\hline
\end{tabular}

Sumber hasil observasi

Berdasarkan table indikator keterampilan berbicara menyimpulkan bahwa keterampilan siswa masih tergolong rendah dan belum baik. Sehingga peneliti memiliki inovasi dengan melakukan penelitian menggunakan metode kuantitatif.

\section{B. TUJUAN}

Penelitian ini bertujuan untuk mengetahui hubungan antara kebiasaan literasi terhadap keterampilan berbicara di kelas 3 MIN 1 Pringsewu.

\section{METODE PENELITIAN}

Metode penelitian yaitu adalah suatu metode yang biasa digunakan untuk penelitian melalui beberapa cara dan metode dengan menggunakan metode penelitian secara kuantitatif Jenis penelitian ini adalah penelitian kuantitatif, teknik pengumpulan data menggunakan angket ( kuesioner ) observasi, wawancara. Populasi dalam penelitian ini berjumlah 217 siswa. Sampel dalam penelitian ini adalah 25 siswa dengan teknik cluster di MIN 1 Pringsewu Kecamatan Pringsewu Kabupaten Pringsewu. 
Objek yang ditangani dalam penelitian ini adalah seberapa jauh peran literasi disekolah dalam minat siswa untuk membaca dan berbicara di dalam sekolah agar siswa tersebut mampu membaca dengan lancar tanpa harus menunggu siswa tersebut untuk melakukan nya dan siswa tersebut dibekali dengan ilmu pengetahuan yang ada di perpustakaan sekolah agar siswa senang untuk membaca semua buku di sekolah baik buku pelajaran sekolah maupun buku-buku lain yang ada di dalam perpustakaan. Metode penelitian ini menggunakan metode kuantitaif.

Metode kuantitatif yaitu adalah metode yang mengkuantifikasi ke dalam angka-angka dan analisis datanya menggunakan statistik sebagai alat penelitian. Adapun wawancara, dokumentasi dan angket penelitian yang hasilnya nanti akan dikuantifikasikan ke dalam angka-angka yang sudah ditentukan sesuai dengan ketentuan yang ada. Adapun tahapan penelitian dari metode kuantitatif yaitu; 1) pada tahapan pertama penelitian pertama yaitu tahap persiapan harus menyiapkan instrument angket penelitian yang akan digunakan untuk penelitian di sekolah. 2) tahapan yang kedua yaitu observasi, didalam tahapan observasi ini peneliti melakukan observasi kepada siswa untuk mengetahui sejauh mana siswa mengenai literasi yang ada di sekolah tersebut dengan cara memberikan angket kepada beberapa siswa yang menjadi sampling dalam penelitian tersebut, sehingga peneliti bisa mengambil langsung hasil dari observasi tersebut disekolah.

Daftar pertanyaan (kuisioner) adalah suatu daftar yang berisi prtanyaanpertanyaan untuk tujuan khusus yang memungkinkan seorang analis system untuk mengumpulkan data dan pendapat dari para siswa yang telah dipilih. Daftar pertanyaan ini kemudian akan dikirim kepada para siswa yang akan mengisi angket kuesioner tersebut sesuai dengan pendapat mereka. Kuesioner (angket) merupakan teknik pengumpulan data yang dilakukan dengan cara memberikan seperangkat pertanyaan atau pernyataan tertulis kepada setiap siswa yang akan diteliti agar siswa tersebut mampu menjawab, dimana peneliti tidak langsung bertanya jawab dengan siswa.

Karena angket dijawab atau diisi oleh siswa langsung dan peneliti bertemu langsung dengan siswa tersebut, maka dalam penyusunan angket perlu diperhatikan beberapa hal. Pertama, sebelum sebuah pertanyaan diberikan kepada siswa, peneliti memberikan arahan terlebih dahulu kepada siswa tersebut sesuai dengan petunjuk pengisian. Kedua, setelah pertanyaan tersebut diberikan kepada masing-masing siswa, peneliti mengarahkan agar siswa segerab mengisi angket yang telah diberikan kepada masing-masing siswa tersebut yang telah dirumuskan dengan menggunakan pertanyaan yang sesuai dengan apa yang ingin diteliti. Ketiga, untuk setiap pertanyaan yang terbuka dan berstruktur disediakan kolom untuk menuliskan jawaban atau respon dari siswa dengan jawaban yang secukupnya.

\section{HASIL DAN PEMBAHASAN}

Berdasarkan hasil analisi uji
regression diketahui membandingkan nilai $\mathrm{t}$ hitung dan $\mathrm{t}$ table sebagai berikut:

1. Jika nilai t hitung $>$ dari t table artinya variable bebas berpengaruh terhadap variable terikat

2. Jika nilai t hitung tidak < dari nilai $\mathrm{t}$ table yaitu artinya variable bebas tidak berpengaruh terhadap variable terikat.

Hasil penelitian yang telah dilakukan di sekolah bahwa masih banyak ditemukan siswa yang belum lancar dalam membaca dan masih banyak pula siswa yang berbicaranya belum lancar sehingga perkembangan anak menjadi terhambat karena kurangnya minat anak untuk membaca diperpustakaan sekolah maupun didalam kelas sehingga siswa masih belum lancar untuk membaca. Didalam keterkaitan antara literasi dengan keterampilan berbicara anak tersebut harus selalju berhubungan sehingga anak dapat membaca dengan lancar nantinya melalui penerapan literasi disekolah yang dilakukan di MIN 1 Pringsewu Kecamatan Pringsewu Kabupaten Pringsewu. Peneliti akan menyajikan hasil penelitian yang telah ditentukan menggunakan analisis kuantitatif. Penentuan sampel dilakukan dengan menggunakan kuesioner (angket) sehingga jumlah responden dalam penelitian berjumlah 15 siswa kelas 3 yang aktif maupun siswa yang pasif dalam penelitian tersebut. Dalam hal ini peneliti sudah mencoba uji regressin yang sudah output data ke dalam SPSS beserta penjelasan nya. 
Tabel 1 : Model Summary

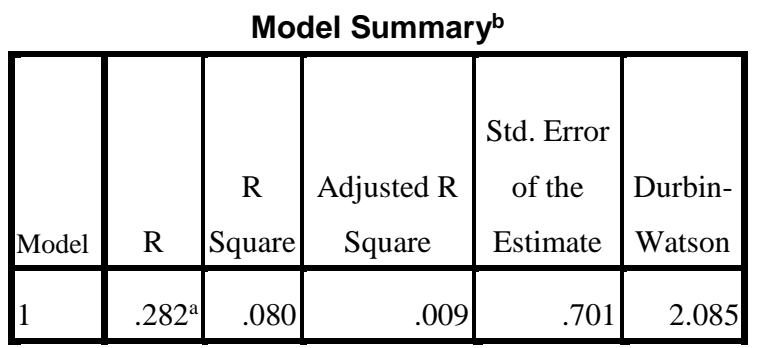

a. Predictors: (Constant), literasi

b. Dependent Variable:

berbicara

Output bagian pertama ( Model Summary ) table diatas dapat dijelaskan besarnya nilai korelasi / hubungan ( $\mathrm{R}$ ) yaitu sebesar 0,282 dan dijelaskan besarnya presentase pengaruh variable bebas terhadap variable terikat yang disebut kofisien determinasi yang merupakan hasil dari penguadratan R. Dari output

tersebut diperoleh koefisien determinasi ( $\mathrm{R}$ ) sebesar 0,282 yang mengandung pengertian bahwa pengaruh variable bebas ( Trust ) terhadap variable terikat partisipasi ) adalah 28,2\%. Sedangkan sisanya dipengaruhi oleh variable yang lainnya.

Tabel 2 : ANOVA

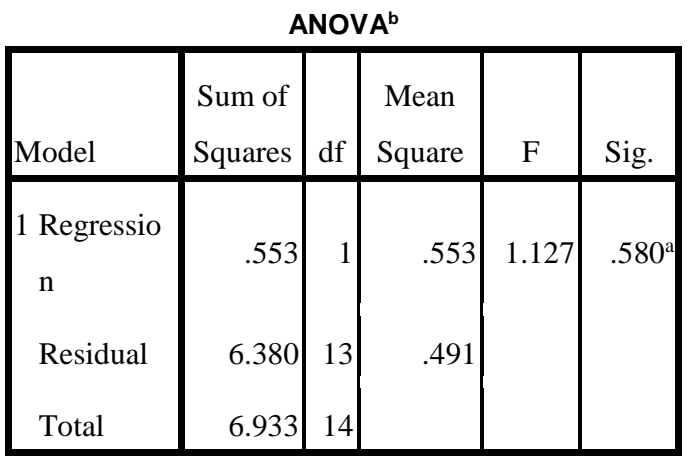

a. Predictors:

(Constant), literasi

b. Dependent

Variable: berbicara
Output bagian kedua ( INOVA) pada bagian ini untuk menjelaskan apakah pengaruh yang nyata ( signifikan ) variable trust ( $\mathrm{X}$ ) terhadap variable partisipan ( Y ). Dari output tersebut terlihat bahwa Fhitung $=0,1.127$ dengan tingkat signifikan / probabilitas 0,580 > 0,05 maka model regresi dapat dipakai untuk memprediksi variable partisipasi.

\section{Tabel 3 : Coefficients}

\section{Coefficients $^{a}$}

\begin{tabular}{|l|r|r|r|r|r|}
\hline Model & $\begin{array}{r}\text { Unstandardize } \\
\mathrm{d} \text { Coefficients }\end{array}$ & \multicolumn{2}{|c|}{$\begin{array}{c}\text { Standardized } \\
\text { Coefficients }\end{array}$} & $\mathrm{T}$ & Sig. \\
\hline & $\mathrm{B}$ & $\begin{array}{c}\text { Std. } \\
\text { Error }\end{array}$ & Beta & & \\
\hline $1 \quad \begin{array}{c}\text { (Const } \\
\text { ant })\end{array}$ & 5.491 & 1.683 & & 3.263 & .006 \\
literasi & .160 & .150 & .282 & 1.061 & .308 \\
\hline
\end{tabular}

a. Dependent Variable:

berbicara

Output ketiga ( Coeficients ) pada table coefisient pada kolom B constanta ( a ) adalah 5,491, sedangkan nilai trust ( b ) adalah $0,160 \%$ sehingga persamaan regresinya dapat ditulis:

$$
\mathrm{Y}=\mathrm{a}+\mathrm{bx}
$$

Atau 5,941+0,160 x koefisien b dinamakan arah regresi dan menyatukan perubahan rata - rata variable y untuk setiap perubahan ini merupakan pertambahan bila $\mathrm{b}$ bertanda positif dan penurunan bila $b$ bertanda negative. Sehingga dari persamaan dapat diterjemahkan:

1. Konstanta sebesar 5,941 menyatakan bahwa jika tidak ada nilai trust maka nilai partisipan sebesar 5,941.

2. Koefisien regresi $X$ sebesar ( 160$)$ menyatakan bahwa nilai partisipan berkurang $16 \%$. Uji regresi terdapat pada hipotesis:

1. $\mathrm{H} 0=$ tidak ada pengaruh yang nyata ( signifikan ) variable trust $(\mathrm{x})$ terhadap variable ( y ) 
2. $\mathrm{H} 1$ = ada pengaruh yang nyata ( signifikan ) variable trust $(\mathrm{x})$ terhadap variable ( Y )

Dari output di atas dapat di ketahui nilai $\mathrm{t}$ hitung $=3,263$ dengan nilai signifikan 0,580>0,05, maka Ho ditolak dan $\mathrm{H} 1$ diterima yang berarti ada pengaruhnya yang nyata ( signifikan ) variable trust $(\mathrm{x}$ ) terhadap variable partisipan ( Y ).

\section{E. KESIMPULAN DAN SARAN}

\section{KESIMPULAN}

Berdasarkan hasil penelitian dan pembahasan yang telah diuraikan sebelumnya, maka dapat disimpulkan sebagai berikut. Setelah menggunbakan uji regression dalam SPSS kelas 3 MIN 1 Pringsewu dalam judul penelitian hubungan antara kebiasaan literasi terhadap keterampilan berbicara di kelas 3 MIN 1 Pringsewu tahun ajaran 2019 / 2020 Kecamatan Pringsewu Kabupaten Pringsewu yang dapat dilihat dari keterkaitan literasi terhadap berbicara yang ada di kelas 3. Dari output tersebut diperoleh koefisien determinasi ( $\mathrm{R}$ ) sebesar 0,282 yang mengandung pengertian bahwa bahwa pengaruh variable bebas ( Trust ) terhadap variable terikat ( partisipasi ) adalah 28,2\%. Dari output di atas dapat di ketahui nilai t hitung $=3,263$ dengan nilai segnifikan $0,580>0,05$, maka $\mathrm{H} 0$ ditolak dan $\mathrm{H} 1$ diterima yang berarti ada pengaruhnya yang nyata ( signifikan ) variable trust ( $\mathrm{x}$ ) terhadap variable partisipan ( $\mathrm{Y}$ ). Maka keterampilan berbicara akan meningkat sebesar 160. Karena nilai koefisien regresi bernilai positif $(+)$, maka dengan demikian dapat dikatakan bahwa literasi ( $\mathrm{x}$ ) berpengaruh positif terhadap keterampilan berbicara ( $\mathrm{Y}$ ). Sehingga persamaan $\mathrm{Y}=5,491+160$

\section{SARAN}

Berdasarkan hasil penelitian di atas peneliti memberikan saran agar dapat termotivasi untuk lebih semangat lagi belajar nya :

Kepada siswa

Diharapkan agar setiap siswa di berikan bimbingan supaya siswa yang malas untuk lebih giat lagi belajar dan membaca agar siswa tersebut menjadi siswa yang rajin dan ulet.

Kepada guru

Diharapakan kepada semua dewan guru agar dapat meningkatkan minat siswa untuk rajin membaca di dalam perpustakaan sekolah yang sudah ada sejak dulu agar semua pembelajaran menjadi lebih efektif lagi dan semua siswa yang pasif menjadi aktif karena guru membimbing nya dengan sabar sehingga semua murid menjadi termotivasi dari guru yang ada di sekolah tersebut. Dan pihak sekolah pun harus bekerja sama dengan wali murid agar siswa lebih rajin untuk belajar di rumah maupun belajar di sekolah.

\section{DAFTAR PUSTAKA}

A’yuni, Qory Qurratun. 2015. Literasi Digital

Remaja Di Kota Surabaya. Skipsi.

UNAIR: Surabaya

Azwar, Sarifuddin. 1998. Metode Penelitian.

Pustaka Belajar: Yogyakarta

Barbara, Santa. 2009. Online Literacy and Trouble with Information. Disertai. University of

California

Costa dan Kallick (2009). Habits of Mind Across

the Curriculum: Practial and Creative Strategies

for Teachers. Alexandria, Virginia USA: ASCD

Iriantara, Yosal. Literasi Media Apa, Mengapa

Bagaimana. 2009. Simbiosa Rekatama Media:

Bandung

Moeleong, Lexy. 2004. Metode Penelitian

Kuantitatif. PT. Remaja Rosdakarya: Bandung

Morocco, C.C. et al. (2008). Supported Literacy for

Adolescents: Transforming Teaching and

Content Learning for The Twenty-First 
Century. Jossey-Bass A Wiley Imprint San

Franscisco

Sugiyono. 2009. Metode Penelitian Kuantitatif,

Kuantitatif, dan $R \& D$. Alfabeta: Bandung

Wray, D. et al (2004). Teaching Literacy

Effectively in the Primary School. Routledge

Falmeer. London 
